\title{
Antibiotic resistance and genetic diversity in water-borne Enterobacteriaceae isolates from recreational and drinking water sources
}

\author{
S. Kumar • V. R. Tripathi $\cdot$ S. K. Garg
}

Received: 28 January 2012/Revised: 28 April 2012/ Accepted: 25 September 2012/Published online: 21 November 2012

(C) CEERS, IAU 2012

\begin{abstract}
A total of 240 water-borne bacteria including 72 Escherichia coli, 83 Enterobacter, 30 Klebsiella, 36 Salmonella and 19 Shigella spp. isolates from drinking and recreational water sources were assessed for antibiotic resistance and genetic diversity. Escherichia coli $(88.89 \%)$ and species of Enterobacter $(86.75 \%)$, Klebsiella $(83.33 \%)$ and Salmonella $(100 \%)$ were resistant to cefadroxil, while $>94 \%$ Shigella spp. were resistant to cefaclor and cefuroxime. Ofloxacin was the most effective antibiotic against isolates of all the genera. Multiple antibiotic resistance index identified dug well, pond and piped water supplies as high risk sources of enteric pathogens. Random amplified polymorphic DNA analysis and restriction fragment length polymorphism of amplified $16 \mathrm{~S}$ rRNA gene were studied for genetic relatedness of Enterobacteriaceae isolates. Primer P1254 identified 10, 16, 4, 4 and 1 distinct random amplified polymorphic DNA group(s) of E. coli, Enterobacter, Klebsiella, Salmonella and Shigella species, respectively. Unlike random amplified polymorphic DNA, restriction fragment length polymorphism using AluI and HaeIII could not segregate isolates in different genetic profiles. 16S rRNA gene of three Enterobacter spp. strains from different sources with similar restriction fragment length polymorphism but different random amplified polymorphic DNA patterns was sequenced, and identified as Enterobacter hormaechei strains skg0061, 0062 and 0063 . The sequence
\end{abstract}

\footnotetext{
S. Kumar · V. R. Tripathi · S. K. Garg (凶)

Centre of Excellence, DST-FIST Supported Department

of Microbiology, Dr. Ram Manohar Lohia Avadh University,

Faizabad, UP 224001, India

e-mail: sk_garg001@yahoo.com

S. Kumar

e-mail: shailendra.microbio@gmail.com

V. R. Tripathi

e-mail: trip.vins@gmail.com
}

information has been submitted to GenBank (HQ322393-95). Biochemically similar but genetically diverse Enterobacteriaceae members from drinking and recreational water sources exhibited varying antibiotic sensitivity. Contamination of water sources with such multiple antibiotic-resistant enteric pathogens poses threat to human health.

Keywords Water sources - Enteric bacteria . 16S rRNA gene - Multiple antibiotic resistance index . Random amplified polymorphic DNA

\section{Introduction}

Water is a vital source of life on the earth. The urban development and improved agriculture practices have been leading to shortage and deterioration of water quality. The underground water is becoming highly polluted due to increased anthropogenic activities. Every effort should be made to achieve safest quality water (WHO 2008). Diarrheal diseases are the major health risk associated with water-borne microbial pathogens. The pathogenic members of Enterobacteriaceae causing gastroenteritis are frequently reported from recreational as well as drinking waters (WHO 2008; Bhagat 2011).

Ayodhya-Faizabad, twin holy Hindu pilgrimage Indian cities with $2,643 \mathrm{~km}^{2}$ area and 2.76 million population are located on the bank of river Saryu (Ghaghra) originating from Himalaya in Nepal. Water in the region is available from river, kunds (holy ponds), ponds, tube well, hand pumps, piped supply and dug wells. The drinking water source is primarily hand pump and piped water while others are used for religious and agricultural activities. The presence of Enterobacteriaceae members in water has been considered as an indicator of faecal contamination (Tewari 
et al. 2003; Kumar et al. 2012). It is correlated with several undocumented outbreaks of gastrointestinal infection causing diarrheal diseases among native as well as visiting population of twin densely populated cities Ayodhya and Faizabad. The diarrheal diseases associated with Enterobacteriaceae are major health problems of the population living with inadequate sanitation and hygiene in developing countries (PulseNetUSA 2004).

Resistance to multiple antibiotics is recognized as an emerging problem worldwide. An indiscriminate use of antibiotics is considered the most important reason for emergence, selection and dissemination of antibioticresistant pathogenic bacteria (Sayah et al. 2005). Over the time, selection pressure allows resistant bacteria to evolve specific pattern for resistance to the antimicrobial agents (Troy et al. 2002). The extensive use and abuse of antibiotics in human infectious disease treatment has resulted in co-existence of multiple antibiotic-resistant and -sensitive bacteria in the natural reservoirs. Multiple antibiotic resistance (MAR) indexing is a useful tool for assessment of high-risk environments contaminated with multiple antibiotic-resistant pathogens (Krumperman 1983).

The water-borne enteric pathogens are identified microbiologically, biochemically, serologically and genetically. The conventional microbiological and biochemical methods inadequately differentiate closely related organisms, and are time consuming. Nowadays, various typing techniques of moderate discriminatory ability such as biotyping, serotyping, phage typing and antibiogram typing are in vogue (Kilic et al. 2009).

Molecular approaches are most rapid and definitive for identification of pathogenic enterobacteria (Li et al. 2004). Random amplified polymorphic DNA (RAPD) analysis is widely used to differentiate Enterobacteriaceae members, viz., Salmonella serotypes (Betancor et al. 2004) and E. coli O157:H7 strains (Kim et al. 2005). Heterogeneity of $16 \mathrm{~S}$ rRNA genes can successfully be used to establish the taxonomic relatedness of microorganisms (Blumberg et al. 1991). There are several techniques based on analysis of $16 \mathrm{~S}$ rRNA gene including restriction fragment length polymorphism (RFLP) and sequencing. The RFLP analysis of amplified DNA has been proposed as valuable tool for epidemiological typing of microorganisms (Shangkuan et al. 2000; Gray et al. 2001).

In the present study, antibiotic resistance pattern of 240 Enterobacteriaceae isolates from different water sources in and around Ayodhya-Faizabad has been studied. RAPD and PCR-RFLP were employed to study the genetic relatedness of the isolates. The relationship between antibiotic sensitivity and genetic diversity of the isolates has been explored. 16S rRNA gene sequencing of three representative Enterobacter spp. isolates from different sources and their subsequent phylogenetic analysis was also performed to elucidate contamination of different sources with common Enterobacteriaceae members.

\section{Materials and methods}

\section{Bacterial isolates}

Water-borne Enterobacteriaceae cultures (240) were isolated from recreational and drinking water sources, e.g., river, ponds, kunds, hand pumps, piped supply and dug wells. The isolates were identified using standard biochemical tests for the members of Enterobacteriaceae as per Bergey's Manual of Systematic Bacteriology (Holt et al. 1993). The identified isolates were Escherichia coli (72), Klebsiella spp. (30), Enterobacter spp. (83), Shigella spp. (19) and Salmonella spp. (36). These were maintained on nutrient agar slants and stored at $4{ }^{\circ} \mathrm{C}$.

\section{Antibiotic sensitivity assay}

Three commonly used classes of antibiotics $\left(\mu \mathrm{g} \operatorname{disc}^{-1}\right)$, fluoroquinolones [ciprofloxacin (5), ofloxacin (5), pefloxine (5), norfloxacin (10)]; cephalosporin [cefadroxil (30), cefazoline (30), cefaclor (30), cefuroxime (30), ceftriaxone (30), cefotaxime (30), ceftazidime (30)] and aminoglycosides [amikacin (30)], were used for testing antibiotic sensitivity. The standard disk diffusion method was used in order to make an assessment of antibiotic resistance pattern among the Enterobacteriaceae isolates (Bauer et al. 1966).

One hundred microlitre of bacterial inoculum in $\log$ phase (turbidity adjusted to $0.5 \mathrm{McFarland}$ standard) was spread evenly on solidified Müller Hinton agar plate followed by application of commercially available antibiotic discs [6 mm dia., supplied by Oxoid (UK)] using disc dispenser (HiMedia, India). The inoculated Petri dishes were then incubated at $37{ }^{\circ} \mathrm{C}$ for $24 \mathrm{~h}$. The inhibition zone was measured using ruled template (HiMedia, India), and the isolates were classified as sensitive/resistant in accordance with performance standards for antimicrobial disk susceptibility tests recommended by Clinical and Laboratory Standards Institute (CLSI). The experiments were performed in triplicate, and average values were considered for patterns of antibiotic resistance or sensitivity.

Multiple antibiotic resistance (MAR) index

The MAR index for the isolates was calculated as per Krumperman (1983) and Hinton et al. (1984). The MAR index was applied to a sample from which several isolates were taken. 
The MAR index $=y /(n \times x)$; where $y$ is the aggregate antibiotic resistance score of all isolates from the sample, $n$ is the number of antibiotics tested, and $x$ is the number of isolates from the sample.

Random amplified polymorphic DNA analysis

The genomic DNA was isolated from Enterobacteriaceae members as described by Wilson (1997). The purified genomic DNA was used as template for RAPD. Nine primers, viz., P1254: 5'-CCGCAGCCAA-3', OPB-17: 5'-AGGGAACGAG-3', OPA-4: 5'-AATCGGGCTG-3', OPB-15: 5'-CCAGGGTGTT-3', 1252 (784): 5'-GCGGAA ATAG-3', OPE-16: 5'-GGTGACTGTG-3', OPK-01: 5'-CA TTCGAGCC-3', OPP-03: 5'-CTGATACGCC-3', CRA23: 5'-GCGATCCCCA-3' (Neilan 1995; Girão et al. 1999; Betancor et al. 2004) were screened for their suitability in the study. Primer P1254 (5'-CCGCAGCCAA- $\left.3^{\prime}\right)$ was selected for RAPD of isolates. Commercially supplied $\mathrm{GeNei}^{\mathrm{TM}}$ Red Dye PCR Master Mix $(2 \times)$ was used along with template DNA and primer in reaction mixture. The reaction mixture comprised of template $(2 \mu \mathrm{l}, 10 \mathrm{ng})$, primer $(2 \mu \mathrm{l}, 40 \mathrm{pmol})$, deionized water $(8.5 \mu \mathrm{l})$ and $12.5 \mu \mathrm{l}$ Red Dye PCR Master Mix $(2 \times)$. Amplification was performed in thermal cycler (PTC 125, MJ Research, USA). Primary denaturation was done at $94{ }^{\circ} \mathrm{C}$ for $5 \mathrm{~min}$ followed by 30 cycles of denaturation $\left(95^{\circ} \mathrm{C}\right.$ for $\left.1 \mathrm{~min}\right)$, primer annealing $\left(35^{\circ} \mathrm{C}\right.$ for $\left.1 \mathrm{~min}\right)$ and extension $\left(72{ }^{\circ} \mathrm{C}\right.$ for $2 \mathrm{~min}$ ). Final extension was carried at $72^{\circ} \mathrm{C}$ for $5 \mathrm{~min}$. The amplified product was electrophoresed on $1.5 \%$ agarose gel for $2.5 \mathrm{~h}$ at $75 \mathrm{~V}$ with ethidium bromide (EtBr) in the gel. Gel analysis was done on SequentiXGelQuestDNA fingerprinting software (SequentiX-Digital DNA Processing, Klein Raden, Germany) to compare the RAPD pattern of each isolate and generate phylogenetic trees (Müller et al. 2005). Bacterial isolates were analysed in three independent experiments. The fingerprint of the isolates was established by considering clearly and consistently detected amplified bands of $\geq 100 \mathrm{bp}$.

\section{Amplification of $16 \mathrm{~S}$ rRNA gene}

The genomic DNA was used as template for amplification of 16S rRNA gene of bacterial isolates using $27 \mathrm{~F}$ (5'-AGGGTTCGATCCTGGCTCAG- $\left.3^{\prime}\right)$ and 1492R (5'-TA CGGAGACCTTGTTACGACTT- $3^{\prime}$ ) universal primers. The PCR mixture was prepared using $12.5 \mu \mathrm{l} \mathrm{GeNei}{ }^{\mathrm{TM}}$ Red Dye PCR Master Mix $(2 \times), 2 \mu$ of template DNA $(100 \mathrm{ng}), 1 \mu \mathrm{l}$ of each primer $(20 \mathrm{pmol})$ and $8.5 \mu \mathrm{l}$ of deionized water to make up to $25 \mu \mathrm{l}$ of reaction volume. The optimization of annealing temperature was carried out in 96-well gradient PCR machine (Techne, TC-512, UK), and $58.5{ }^{\circ} \mathrm{C}$ was selected as annealing temperature. PCR was performed as previously described. Amplified product was electrophoresed on $0.7 \%$ agarose gel $(w / v)$ in TrisEDTA (TE) amended with EtBr at $50 \mathrm{~V}$ for $2 \mathrm{~h}$. The electropherogram was analysed on Doc It, gel documentation system (UVP, UK) for appearance of single band of amplified product measuring approximately $1,450 \mathrm{bp}$.

\section{PCR-RFLP of 16S rRNA gene}

Two restriction endonucleases, AluI and HaeIII were used for PCR-RFLP of amplified product of 16S rRNA gene (Brunel et al. 1997). The reaction mixture for restriction

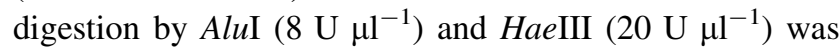
prepared separately by taking $10 \mu \mathrm{l}$ of amplified DNA, $1.5 \mu \mathrm{l}$ of restriction buffer $(10 \times), 2 \mu \mathrm{l}$ of restriction enzyme and $1.5 \mu \mathrm{l}$ of water to make final volume of $15 \mu \mathrm{l}$ reaction mixture. The reaction mixture was incubated for $5 \mathrm{~h}$ at $37{ }^{\circ} \mathrm{C}$ for complete digestion. The digested DNA was electrophoresed on $1.2 \%$ agarose gel $(w / v)$ in TE amended with EtBr at $70 \mathrm{~V}$ for $1 \mathrm{~h}$. The gel was analysed on Doc It, gel documentation system (UVP, UK) for RFLP patterns of digested amplified product of 16S rRNA gene.

\section{S rRNA gene sequencing}

The amplified product of 16S rRNA gene was sequenced on ABI Prism-310 (Applied Biosystems) automated sequencer. The constituents of sequencing reaction were as per manufacturer's recommendation: $1.0 \mu \mathrm{l}$ terminator ready reaction mix, $1.5 \mu \mathrm{l}$ sequencing buffer $(5 \times), 40 \mathrm{ng}$ template (PCR product of 16S rRNA gene), 3.2 pmol primer and deionized water to make up final volume of $10 \mu \mathrm{l}$. The constituents were mixed well and spinned briefly before setting up in thermal cycler. PCR was carried out in 96-well gradient PCR machine (Techne TC-512, UK) as per the instructions of Applied Biosystems. Five primers were used for sequencing: 1100R (5'-AGGGTTGCGCT CGTTG-3 $\left.{ }^{\prime}\right)$, 518R (5'-ATTACCGCGGCTGCTGG-3'), 1114F (5'-GCAACGAGCGCAACCC-3'), 27F (5'-AGGG TTCGATCCTGGCTCAG-3') and 1492R (5'-TACGGAG ACCTTGTTACGACTT-3').

Phylogenetic analysis of 16S rRNA gene sequence

The sequence obtained was then analysed by BLAST and megaBLAST programs against the database of type strains with validly published prokaryotic names. Fifty sequences with highest scores were then selected for calculation of pairwise sequence similarity using global alignment algorithm, which was implemented at the EzTaxon server (Chun et al. 2007). Phylogenetic neighbours were determined using multiple sequence alignment programme in Clustal W (Thompson et al. 1994). Phylogenetic 
relationship among the similarity showing organisms was determined using MEGA 4 software programme (Tamura et al. 2007). The phylogenetic tree was constructed using neighbour-joining (NJ) method and significance of junctions was established using bootstrap (1,000 replicates) method (Felsenstein 1985).

Submission of gene sequence to GenBank

The 16S rRNA gene sequences of isolates were submitted to GenBank database available with National Centre for Biotechnology Information (http://www.ncbi.nlm.nih.gov/ genbank) using bankit on http://www.ncbi.nlm.nih.gov/ BankIt/oldbankit.html (Benson et al. 2007). The accession numbers HQ322393, HQ322394 and HQ322395 were assigned following the submission, and the sequence data were published online by NCBI.

\section{Results and discussion}

\section{Antibiotic sensitivity assay}

All antibiotics exhibited variable effect on water-borne enteric bacterial isolates (Fig. 1). Ofloxacin exerted most profound effect on all the isolates $(92.63 \%)$ with $100 \%$ killing of Shigella strains. All Shigella isolates were also sensitive to ciprofloxacin while, only 78.95 and $68.42 \%$ isolates were sensitive to amikacin and pefloxine, respectively. The sensitivity of other isolates against ciprofloxacin, amikacin and pefloxine was in the order: $85.72>$ $79.64>76.46 \%$, respectively. Majority of Enterobacter isolates $(>90 \%)$ were sensitive to ofloxacin, ciprofloxacin, amikacin and pefloxine with ofloxacin being most effective against $97.59 \%$ isolates. However, ciprofloxacin, pefloxine and amikacin were less efficacious (66.67-83.33\%) against E. coli, Klebsiella spp. and Salmonella spp. The sensitivity of isolates in our study illustrates broad spectrum activity of fluoroquinolone and aminoglycoside group of antibiotics against the water-borne bacterial isolates. It is customary to include fluoroquinolone as one of the most recommended antibiotics for diarrheal treatment (Jiang et al. 2002). The most effective among the fluoroquinolones (Ofloxacin) affects DNA gyrase which is critical for nucleic acid replication (Drlica and Zhao 1997).

Ceftriaxone, norfloxacin, cefotaxime and ceftazidime had moderate effect on the isolates. While Klebsiella $(86.67 \%)$ and E. coli $(83.33 \%)$ were sensitive, $73.68 \%$ Shigella isolates were resistant to ceftriaxone. $E$. coli isolates at 83, 79 and $65 \%$ were sensitive, respectively, to cefotaxime, ceftazidime and norfloxacin; while Enterobacter, Klebsiella and Salmonella isolates were moderately affected (50-85.54\%) by these antibiotics. Shigella spp. displayed relatively greater resistance against ceftriaxone, cefotaxime and ceftazidime. Cefazoline, cefuroxime, cefaclor and cefadroxil were less effective against all the isolates. Though,

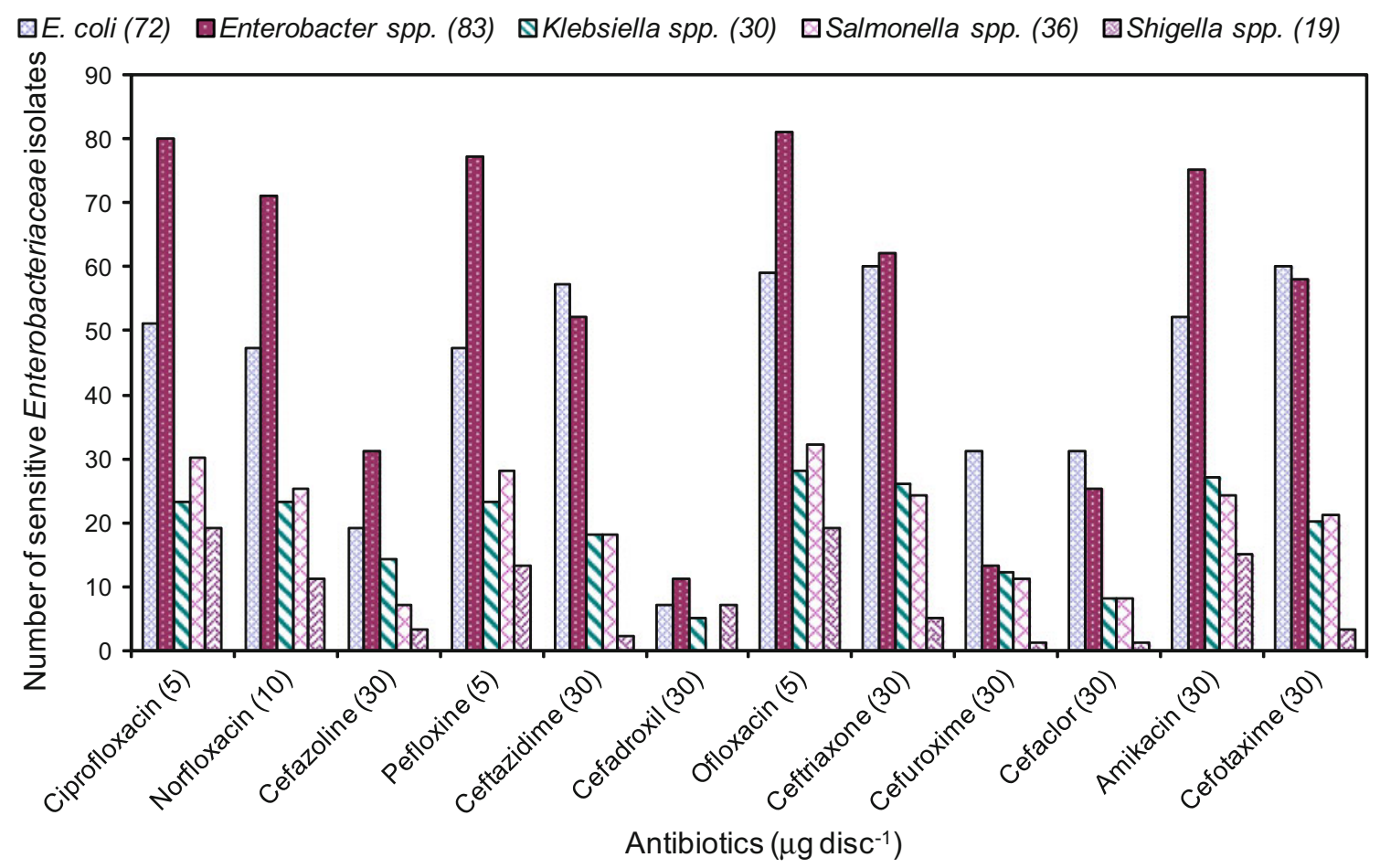

Fig. 1 Antibiotic sensitivity assay of water-borne Enterobacteriaceae isolates 
cefazoline affected $46.67 \%$ Klebsiella, the isolates of other genera were not affected to that extent. Cefadroxil was not effective against Salmonella spp. thereby displaying $100 \%$ resistance (Fig. 1). The pattern of resistance against these antibiotics illustrates the differential potential and relevance of the commonly recommended drugs against water-borne gastrointestinal pathogens. Therefore, it is recommended to regularly evaluate the antibiotic sensitivity of commonly reported water-borne enteric pathogens.

The presence of antibiotic-resistant isolates in water bodies is a serious concern for the densely populated developing countries like India. The environmental reservoirs of antibiotic resistance determinants are poorly understood (Allen et al. 2010). The resistance among the isolates might be related to contamination of sources with antibiotic-resistant Enterobacteriaceae followed by horizontal or vertical transfer of antibiotic resistance trait. It has also been presumed that much of the hospital/industrial/ domestic wastewater does not undergo effective treatment that permits low concentration of antibiotics finding way into water bodies like rivers, lakes, reservoirs, etc. This exposure over period of time provides ideal conditions for transfer of antibiotic resistance (Diwan et al. 2010).

The findings of antibiotic resistance in Enterobacteriaceae are extremely significant as they point towards the prevalence of antibiotic-resistant microorganisms in drinking water sources. It has recently been observed that such multiple drug-resistant bacteria 'superbugs' are the cause of worry for nations worldwide (Walsh et al. 2011). These emerging resistant organisms are tough to treat by conventional antibiotics and add to growing cost of treatment for the people in developing countries. Therefore, such studies assume greater significance and call for regular monitoring of water sources to ensure better and healthy world in future.
RAPD analysis of isolates

Escherichia coli and Enterobacter spp. exhibited 10 and 16 different RAPD band patterns, respectively. The genetic variation was dominated in hand pump water, as $24 \mathrm{E}$. coli and 11 Enterobacter isolates resulted in 5 RAPD patterns each (Table 1). The potable piped water did not reveal much genetic differences in all the isolates of different genera. Surprisingly, species of Salmonella and Shigella were consistently showing less genetic divergence across all the water sources. The random amplification of Polymorphic DNA of Klebsiella spp., Salmonella spp. and Shigella spp. resulted in four, four and one RAPD patterns, respectively. The dendrograms of Escherichia coli, Enterobacter spp., Klebsiella spp. and Salmonella spp. isolates showing genetic relationship are presented, respectively, in Fig. 2a-d.

The dendrogram (Fig. 2b) revealed that Enterobacter spp. had maximum genetic diversity among all the isolates. RAPD patterns suggest the transmission of bacterial isolates from one to other water sources. The recreational water sources (kund and pond) accounted for nearly $70 \%$ of all genetic patterns observed, while drinking water sources had $38 \%$ genetic divergence. Enterobacteriaceae isolates revealed 35 different band patterns of which $42 \%$ were found in drinking water sources (Table 1).

Betancor et al. (2004) segregated Salmonella enterica serotypes using the same primer, and concluded that RAPD PCR discriminated true polymorphism unobtainable by serotyping and phenotypic trait characterization of isolates. The RAPD pattern reflected that different isolates were present in more than one drinking and recreational water sources undermining public health risk in the high population density region. Tewari et al. (2003) also reported similar distributional pattern of pathogenic E. coli and Salmonella serotypes.

Table 1 Distributional pattern of different Enterobacteriaceae isolates from various water sources using RAPD

\begin{tabular}{|c|c|c|c|c|c|c|c|}
\hline \multirow{2}{*}{$\begin{array}{l}\text { Organism } \\
\text { (number of } \\
\text { isolates) }\end{array}$} & \multirow{2}{*}{$\begin{array}{l}\text { Number of } \\
\text { RAPD patterns }\end{array}$} & \multicolumn{6}{|c|}{ Patterns present in water sources } \\
\hline & & Hand pump & $\begin{array}{l}\text { Piped } \\
\text { supply } \\
\text { water }\end{array}$ & Dug well & River & Kund & Pond \\
\hline E. $\operatorname{coli}(72)$ & $10(\mathrm{EC} 1-10)$ & $\begin{array}{l}\text { EC1, EC2, EC3, } \\
\text { EC4, EC5 }\end{array}$ & - & $\begin{array}{c}\text { EC2, } \\
\text { EC4, } \\
\text { EC7 }\end{array}$ & $\begin{array}{l}\text { EC9, } \\
\text { EC10 }\end{array}$ & EC6, EC7 & EC5, EC7, EC8 \\
\hline $\begin{array}{l}\text { Enterobacter spp. } \\
\quad(83)\end{array}$ & $16(\mathrm{EN} 1-16)$ & $\begin{array}{l}\text { EN2, EN10, EN12, } \\
\text { EN13, EN14 }\end{array}$ & EN3 & $\begin{array}{l}\text { EN15, } \\
\text { EN16 }\end{array}$ & EN4 & $\begin{array}{l}\text { EN1, EN8, EN9, } \\
\text { EN10, EN11 }\end{array}$ & $\begin{array}{l}\text { EN1, EN2, EN3, EN4, } \\
\text { EN5, EN6, EN7 }\end{array}$ \\
\hline $\begin{array}{l}\text { Klebsiella spp. } \\
\text { (30) }\end{array}$ & $4(\mathrm{~K} 1-4)$ & $\mathrm{K} 2$ & - & $\begin{array}{l}\mathrm{K} 1, \mathrm{~K} 3, \\
\mathrm{~K} 4\end{array}$ & - & $\mathrm{K} 1, \mathrm{~K} 2$ & $\mathrm{~K} 1, \mathrm{~K} 2, \mathrm{~K} 3, \mathrm{~K} 4$ \\
\hline $\begin{array}{l}\text { Salmonella spp. } \\
\text { (36) }\end{array}$ & $4(\mathrm{~S} 1-4)$ & $\mathrm{S} 1, \mathrm{~S} 2$ & S1 & - & S3 & S3, S4 & $\mathrm{S} 1$ \\
\hline Shigella spp. (19) & 1 (SH1) & SH1 & SH1 & SH1 & - & SH1 & SH1 \\
\hline
\end{tabular}

The data presented above are based on consistent observation of identical bands ( $>100 \mathrm{bp}$ size) present in the gel after amplification. The experiments were repeated thrice to conclude the RAPD patterns observed 


\begin{tabular}{|cc}
\cline { 2 - 2 } $0.07 / 45$ & 0.3750 \\
0.0060 & 0.3750 \\
\cline { 2 - 2 } 0.01490190 & 0.4495 \\
0.0099 & 0.3958 \\
0.0185 & 0.4149 \\
0.0123 & 0.4247 \\
\hline 0.0081 & 0.4432 \\
\hline
\end{tabular}
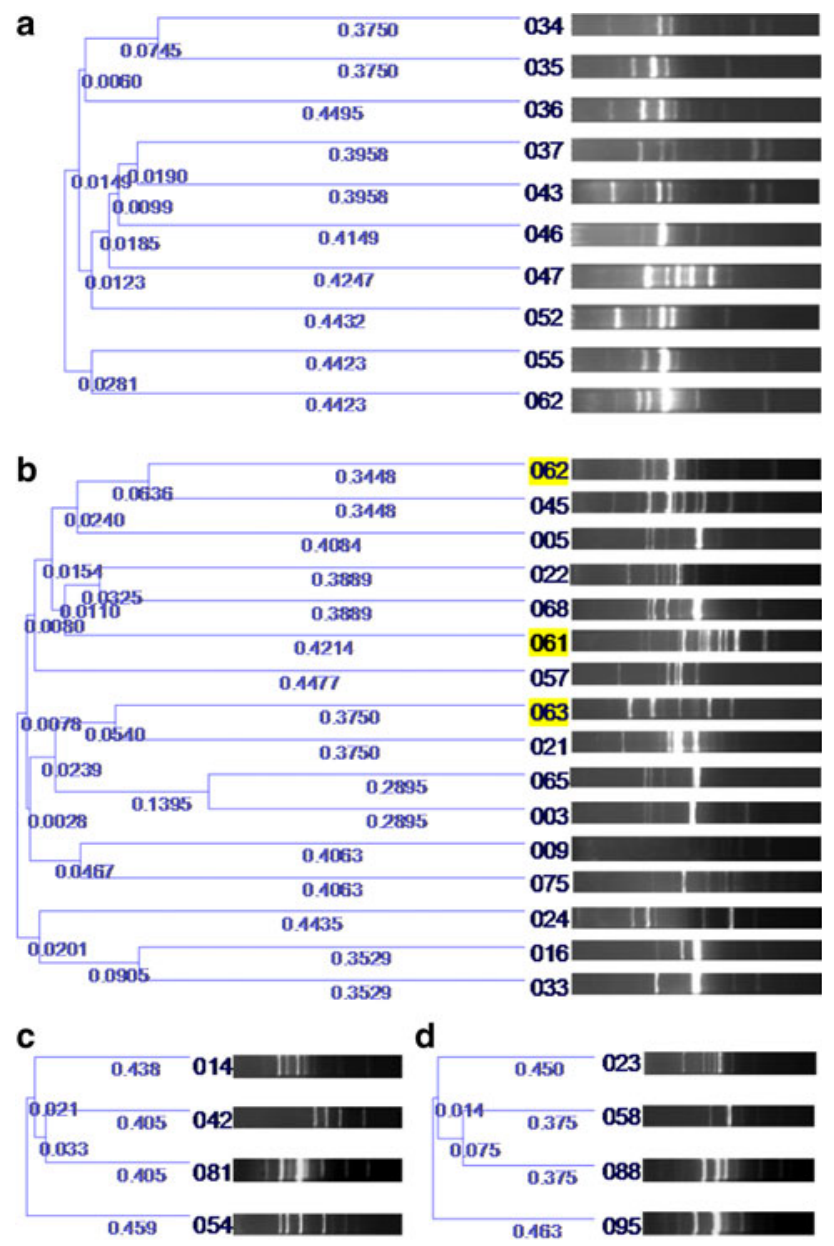

0.100

Fig. 2 Dendrograms generated by GelQuest (Ver 3.02) software showing the relationship of a $10 \mathrm{E}$. coli, b 16 Enterobacter, c four Klebsiella and $\mathbf{d}$ four Salmonella spp. isolates. The analyses of RAPD band patterns were performed using the Jaccard coefficient and UPGMA (unweighted pair group method with arithmetic averages)

The isolates displaying varying resistance/sensitivity patterns to tested antibiotics had similar RAPD profiles. It suggests that genetic alterations which produced resistance do not affect the RAPD profile. This may be due to the acquaintance of antibiotic resistance traits residing on accessory genetic material of the isolates. Similar to our findings, Betancor et al. (2004) demonstrated that antibiotic pressure leading to nalidixic acid resistance, did not alter the RAPD pattern of Salmonella enterica phenotypes.

\section{PCR-RFLP of $16 \mathrm{~S}$ rRNA gene}

Restriction digestion (with HaeIII) of amplified product of $16 \mathrm{~S}$ rRNA gene resulted in different groups of genetically identical isolates. Escherichia coli, Klebsiella spp., Enterobacter spp. and Salmonella spp. were discriminated into two groups of each, while Shigella spp. members were represented by only one RFLP pattern. AluI digestion could develop two RFLP patterns each of E. coli, Enterobacter, Klebsiella and Salmonella spp., while Shigella spp., isolates could not be distinguished genetically, and was represented by a single RFLP pattern.

The PCR-RFLP with HaeIII generates similar genetic profile of various isolates from different genera. While, restriction digestion of PCR amplified product of $16 \mathrm{~S}$ rRNA gene with AluI showed slightly better, but little polymorphism among the isolates of different genera of Enterobacteriaceae. The poor differentiation of isolates must be associated with the conserved sites for restriction digestion of 16S rRNA gene in most of the isolates, as the $16 \mathrm{~S}$ rRNA gene shares over $99 \%$ homology across different genera. RAPD patterns were suggestive of higher subtypes of various generic isolates, while RFLP of $16 \mathrm{~S}$ rRNA gene did not reveal as much subtypes of the genera. It may be due to the availability of higher number of annealing sites for RAPD primers on genomic DNA, but the endonucleases restriction sites in 16S rRNA gene of genera are highly conserved (Woese and Fox 1977; Lane et al. 1985).

Similar to our findings, Iriarte and Owen (1996) reported that PCR-RFLP analysis of 23S rRNA gene of Campylobacter jejuni strains was not very useful in differentiating isolates at subspecies level. Broda et al. (2000) also reported that restriction digestion of $16 \mathrm{~S}$ rRNA gene with AluI, HaeIII and TaqI could not distinguish between Clostridium algidicarnis and Cl. putrefaciens. While, Miteva et al. (2001) reported that amplified ribosomal DNA restriction analysis (ARDRA) is useful for differentiation of bacterial strains at subspecies level due to different EcoRI restriction map of 5S rRNA gene. However, contrary to our findings, Brunel et al. (1997) stressed that PCR-RFLP of 16S rRNA gene using restriction enzymes AluI and HaeIII were effective in differentiating bacterial isolates of different genera including Enterobacteriaceae. The characteristic RFLP profiles may be used as marker for identification of genus members (Kullen et al. 1997), but may not be used to distinguish the isolates genetically.

Multiple antibiotic resistance index and genetic diversity

The different water sources contained Enterobacteriaceae members resistant not only to a single but multiple antibiotics. These organisms in common parlance are referred as MAR bacteria. The MAR index of 0.83 was highest for Salmonella spp. from piped water sources, while the lowest (0.13) MAR index was recorded for Klebsiella spp. isolates from hand pumps (Table 2).

The hand pump water with high MAR index reflected greater genetic variation in E. coli and Enterobacter spp. It 
Table 2 Multiple antibiotic resistance (MAR) index of Enterobacteriaceae isolates from various sources

\begin{tabular}{|c|c|c|c|c|c|}
\hline \multirow[t]{2}{*}{ Water sources } & \multicolumn{5}{|c|}{ MAR Index of Enterobacteriaceae isolates } \\
\hline & E. coli & Enterobacter spp. & Klebsiella spp. & Salmonella spp. & Shigella spp. \\
\hline River & $0.28(12)$ & $0.58(2)$ & A & $0.56(16)$ & $0.50(2)$ \\
\hline Pond & $0.31(12)$ & $0.36(36)$ & $0.36(13)$ & $0.31(3)$ & $0.75(2)$ \\
\hline Kund & $0.33(12)$ & $0.37(20)$ & $0.28(6)$ & $0.40(10)$ & $0.53(6)$ \\
\hline Hand pump & $0.42(24)$ & $0.23(11)$ & $0.13(4)$ & $0.28(5)$ & $0.58(2)$ \\
\hline Piped supply & $0.38(2)$ & $0.71(4)$ & A & $0.83(2)$ & $0.64(6)$ \\
\hline Dug well & $0.68(10)$ & $0.33(10)$ & $0.62(7)$ & A & 0.08 (1) \\
\hline
\end{tabular}

Values in parentheses are the number of isolates

A: no isolates of the species were obtained from the source

is observed that hand pump water is used for drinking purpose, which enhances high risk of water-borne infections. Though the MAR index was high (0.71) for Enterobacter spp. in piped supply water, it did not reveal any genetic variation. Similarly, Shigella spp. did not reveal diversity apparent in molecular studies despite having high MAR index in all the water sources except dug well. Hand pump and kund water sources showed high genetic divergence of Salmonella spp. isolates despite moderate MAR index (0.3-0.4). Maximum diversity of Klebsiella spp. was observed in dug well and pond water while MAR index was high (0.62) in dug well only. MAR index suggested dug well, pond and piped supply waters as high risk sources for multi-resistant strains of enterobacteria. The local ponds may apparently be contaminated with antibiotic-resistant bacteria through domestic and industrial waste water discharge. The dug wells are seldom used and therefore, have become dumping sites of domestic waste. The high MAR index of isolates from piped supply might be due to contamination with sewage MAR bacteria through loose connections, rusted and broken pipes passing through underground sewage (WHO 2008).

Hence, it may be concluded that antibiotic selection pressure led to greater genetic diversity, and thus differences in molecular profile of the isolates. Conversely, the reverse was also observed where low genetic diversity was evident despite high MAR index.

Molecular identification and phylogenetic analysis of Enterobacter spp.

Three isolates of Enterobacter spp. characterized as different RAPD, but same RFLP group members were identified by sequencing 16S rRNA gene. The BLAST and megaBLAST analysis of gene sequences of isolates showed maximum homology ( $>99.4 \%$ ) with Enterobacter hormaechei CIP 103441(T). The Enterobacter hormaechei is of human origin, which was isolated originally from blood, wounds, sputum, and was named in the honour of Estenio Hormaeche, an Uruguayan microbiologist who (with P. R. Edwards) proposed and defined the genus Enterobacter. The species is negative for indole production but produces $\mathrm{H}_{2} \mathrm{~S}$. Originally, most of the isolates were reported moderately sensitive to several antibiotics but resistant to ampicillin, cefoxitin and cephalothin (O'Hara et al. 1989). The studied isolates were designated as Enterobacter hormaechei strains skg0061, 0062 and 0063 from pond, hand pump and kund, respectively (Fig. 3). Sequence information was submitted in GenBank database NCBI with accession numbers HQ322393, HQ322394 and HQ322395, respectively, for Enterobacter hormaechei strains skg0061, 0062 and 0063 . The phylogenetic neighbours were analysed by Clustal $\mathrm{W}$, and $\mathrm{NJ}$ tree was constructed using MEGA 4 software.

The 16S rRNA gene sequencing followed by database search is frequently used for identification and taxonomic study of bacterial isolates (Amann et al. 1994). Identification of genus and species by 16S rRNA gene sequencing has been useful (Janda and Abbott 2007). The genotypic characterization using conserved sequences such as the small-subunit (16S) rRNA gene provides the basis for ongoing evaluation and restructuring of bacterial systematics (Kirschner et al. 1993; Ludwig and Schleifer 1994). The present study revealed the contamination of different water sources with identical Enterobacteriaceae members.

\section{Conclusion}

The water-borne Enterobacteriaceae isolates from various sources in study region were resistant to antibiotics of one or more classes. Fluoroquinolones were most effective antibiotics against the isolates, while cefadroxil was least effective. High risk sources (dug well, pond, piped supply water) contaminated with multiple antibiotic-resistant Enterobacteriaceae members were identified by MAR 
Fig. 3 The phylogenetic tree is constructed to show evolutionary relationships of Enterobacter hormaechei strains skg0061 (HQ322393), 0062 (HQ322394) and 0063 (HQ322395) using neighbourjoining method. Bootstrap values for 1,000 replicates are shown at branch points. Branches corresponding to partitions reproduced in $<50 \%$ bootstrap replicates are collapsed. The evolutionary distances were computed using the maximum composite likelihood method, and are in the units of the number of base substitutions per site. All positions containing gaps and missing data were eliminated from the dataset (complete deletion option)

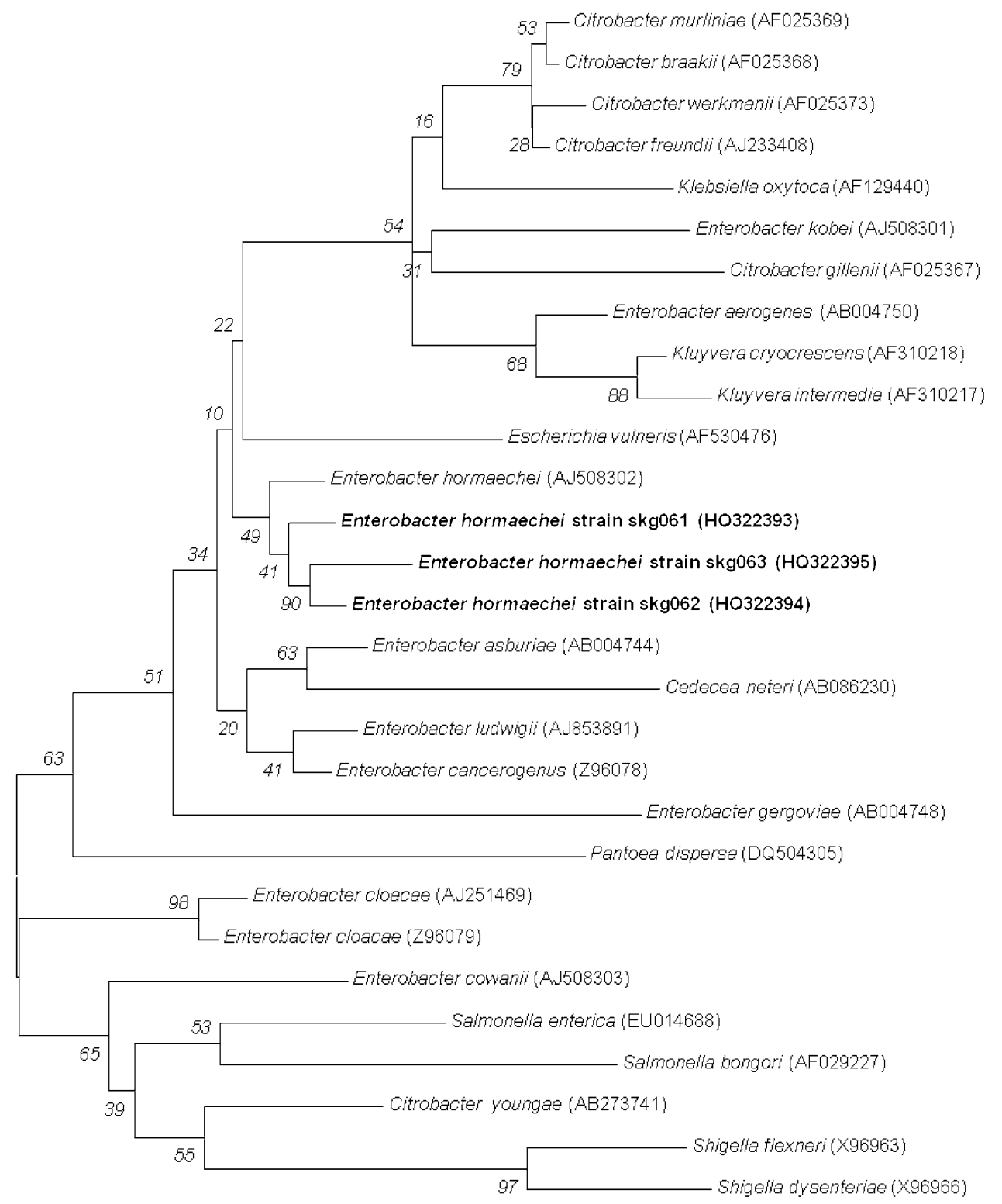

indexing. The isolates having identical RAPD profile showed varied antibiotic sensitivity patterns. Enterobacter spp. isolates from different sources having identical PCRRFLP but different RAPD patterns were identified as strains of Enterobacter hormaechei by 16S rRNA gene sequencing and phylogenetic study.

Acknowledgments The authors are highly thankful to the University Grants Commission, New Delhi, India for financial support under minor research project [No. 33-465/2007(SR)]. The assistance by the Department of Science and Technology, Government of India under FIST programme and Government of Uttar Pradesh under Centre of Excellence scheme to our department is duly acknowledged. We are extremely thankful to Late Dr. Rakesh K. Jain and Mr. Surendra Vikram, Institute of Microbial Technology, Chandigarh, India for support, constant encouragement and facility for gene sequencing related works.

Conflict to interest The authors declare that they have no conflict to interest.

\section{References}

Allen HK, Donato J, Wang HH, Cloud-Hansen KA, Davies J, Handelsman J (2010) Call of the wild: antibiotic resistance genes in natural environments. Nature Rev Microbiol 8:251-259

Amann R, Ludwig W, Schleifer KH (1994) Identification of uncultured bacteria: a challenging task for molecular taxonomists. ASM News 60:360-365 
Bauer AW, Kirby WM, Sherris JC, Turck M (1966) Antibiotic susceptibility testing by a standardized single disk method. Am J Clin Pathol 45:493-496

Benson DA, Karsch-Mizrachi I, Lipman DJ, Ostell J, Wheeler DL (2007) GenBank. Nucleic Acids Res 35(Database issue):21-25

Betancor L, Schelotto F, Martinez A, Pereira M, Algorta G, Rodríguez MA, Vignoli R, Chabalgoity JA (2004) Random amplified polymorphic DNA and phenotyping analysis of Salmonella enterica serovar enteritidis isolates collected from humans and poultry in Uruguay from 1995 to 2002. J Clin Microbiol 42:1155-1162

Bhagat S (2011) Faecal bacteria found in drinking water samples. Times of India, 26 Feb 2011. http://timesofindia.indiatimes.com/ city/mumbai/Faecal-bacteria-found-in-drinking-water-samples/ articleshow/7578211.cms??prtpage $=1$. Viewed 8 April 2011

Blumberg HM, Kiehlbauch JA, Wachsmuth IK (1991) Molecular epidemiology of Yersinia enterocolitica O:3 infections: use of chromosomal DNA restriction fragment length polymorphisms of rRNA genes. J Clin Microbiol 29:2368-2374

Broda DM, Musgrave DR, Bell RG (2000) Use of restriction fragment length polymorphism analysis to differentiate strains of psychrophilic and psychrotrophic clostridia associated with 'blown pack' spoilage of vacuum packed meats. J Appl Microbiol $88: 107-116$

Brunel B, Givaudan A, Lanois A, Akhurst RJ, Boemare N (1997) Fast and accurate identification of Xenorhabdus and Photorhabdus species by restriction analysis of PCR-amplified 16S rRNA genes. Appl Environ Microbiol 63:574-580

Chun J, Lee JH, Jung Y, Kim M, Kim S, Kim BK, Lim YW (2007) EzTaxon: a web-based tool for the identification of prokaryotes based on 16S ribosomal RNA gene sequences. Int J Syst Evol Microbiol 57:2259-2261

Diwan V, Tamhankar AJ, Khandal RK, Sen S, Aggarwal M, Marothi Y, Iyer RV, Sundblad-Tonderski K, Stålsby-Lundborg C (2010) Antibiotics and antibiotic-resistant bacteria in waters associated with a hospital in Ujjain, India. BMC Public Health 10:414

Drlica K, Zhao X (1997) DNA gyrase, topoisomerase IV, and the 4-quinolones. Microbiol Mol Biol Rev 61:377-392

Felsenstein J (1985) Confidence limits on phylogenies: an approach using the bootstrap. Evolution 39:783-791

Girão DM, Bando SY, Girão VBC, Moreira-Filho CA, Fracalanzz SEL, Trabulsi LR, Monteiro-Neto V (1999) Characterization of typical and atypical enteropathogenic Escherichia coli (EPEC) strains of the classical O55 serogroup by RAPD analysis. Revista de Microbiologia 30:365-368

Gray JT, WaKabongo M, Campos FE, Diallo AA, Tyndal C, Tucker CA (2001) Development recognition of Yersinia enterocolitica multiple strain infection in twin infants using PCR-based DNA fingerprinting. J Appl Microbiol 90:358-364

Hinton M, Rixson PD, Allen V, Linton AH (1984) The persistence of drug resistant Escherichia coli strains in the majority faecal flora of calves. J. Hygiene Lond 93:547-557

Holt JG, Krieg NR, Sneath PHA, Staley JT, Williams ST (1993) Bergey's manual of determinative bacteriology, 9th edn. Williams and Wilkins, Baltimore

Iriarte P, Owen RJ (1996) PCR-RFLP analysis of the large subunit (23S) ribosomal RNA genes of Campylobacter jejuni. Lett Appl Microbiol 23:163-166

Janda JM, Abbott SL (2007) 16S rRNA gene sequencing for bacterial identification in the diagnostic laboratory: pluses, perils, and pitfalls. J Clin Microbiol 45:2761-2764

Jiang ZD, Lowe B, Verenkar MP, Ashley D, Steffen R, Tornieporth N (2002) Prevalence of enteric pathogens among international travellers with diarrhea acquired in Kenya (Mombasa), India (Goa), or Jamaica (Montego Bay). J Infect Dis 185:497-502
Kilic A, Muz A, Ertas HB, Özbey G (2009) Random amplified polymorphic DNA (RAPD) analysis of Escherichia coli isolated from chickens. F Ü Sağ Bil Vet Derg 23:1-4

Kim JY, Kim SH, Kwon NH, Bae WK, Lim JY, Koo HC, Kim JM, Noh KM, Jung WK, Park KT, Park YH (2005) Isolation and identification of Escherichia coli O157:H7 using different detection methods and molecular determination by multiplex PCR and RAPD. J Vet Sci 6:7-19

Kirschner P, Springer B, Vogel U, Meier A, Wrede A, Kiekenbeck M, Bange FC, Bottger EC (1993) Genotypic identification of mycobacteria by nucleic acid sequence determination: report of a 2-year experience in a clinical laboratory. J Clin Microbiol 31:2882-2889

Krumperman PH (1983) Multiple antibiotic resistance indexing of Escherichia coli to identify high-risk sources of fecal contamination of foods. Appl Environ Microbiol 46(1):165-170

Kullen MJ, Amann MM, O'Shaughnessy MJ, O'Sullivan DJ, Busta FF, Brady LJ (1997) Differentiation of ingested and endogenous bifidobacteria by DNA fingerprinting demonstrates the survival of an unmodified strain in the gastrointestinal tract of humans. J Nutr 127:89-94

Kumar S, Tripathi VR, Garg SK (2012) Physicochemical and microbiological assessment of recreational and drinking waters. Environ Monit Assess 184:2691-2698. doi:10.1007/s10661-011-2144-1

Lane DJ, Pace B, Olsen GJ, Stahl DA, Sogin ML, Pace NR (1985) Rapid determination of $16 \mathrm{~S}$ ribosomal RNA sequences for phylogenetic analyses. Proc Natl Acad Sci USA 82:6955-6959

Li JW, Shi XQ, Chao FH, Wang XW, Zheng JL, Song N (2004) A study on detecting and identifying enteric pathogens with PCR. Biomed Environ Sci 17:109-120

Ludwig W, Schleifer KH (1994) Bacterial phylogeny based on 16S and 23S rRNA sequence analysis. FEMS Microbiol Rev 15:155-173

Miteva V, Boudakov I, Stoyancheva GI, Marinova B, Mitev V, Mengaud J (2001) Differentiation of Lactobacillus delbrueckii subspecies by ribotyping and amplified ribosomal DNA restriction analysis (ARDRA). J Appl Microbiol 90:909-918

Müller J, Friedl T, Hepperle D, Lorenz M, Day JG (2005) Distinction between multiple isolates of Chlorella vulgaris (Chlorophyta, Trebouxiophyceae) and testing for conspecificity using amplified fragment length polymorphism and ITS rDNA sequences. J Phycol 41:1236-1247

Neilan BA (1995) Identification and phylogenetic analysis of toxigenic cyanobacteria by multiplex randomly amplified polymorphic DNA PCR. Appl Environ Microbiol 61:2286-2291

O'Hara CM, Steigerwalt AG, Hill BC, Farmer III JJ, Fanning GR, Brenner Don J (1989) Enterobacter hormaechei, a new species of the family Enterobacteriaceae formerly known as enteric group 75. J Clin Microbiol 27:2046-2049

PulseNetUSA (2004) One day (24-28 h) standardized laboratory protocol for molecular subtyping of Escherichia coli O157:H7, non-typhoidal Salmonella serotypes, and Shigella sonnei by pulsed-field gel electrophoresis (PFGE). CDC, National Center for Infectious Diseases, Atlanta

Sayah RS, Kaneene JB, Johnson Y, Miller RA (2005) Patterns of antimicrobial resistance observed in Escherichia coli isolates obtained from domestic- and wild-animal fecal samples, human septage, and surface water. Appl Environ Microbiol 71:1394-1404

Shangkuan YH, Yang JF, Lin HC, Shaio MF (2000) Comparison of PCR-RFLP, ribotyping and ERIC-PCR for typing Bacillus anthracis and Bacillus cereus strains. J Appl Microbiol 89:452-462

Tamura K, Dudley J, Nei M, Kumar S (2007) MEGA4: molecular evolutionary genetics analysis (MEGA) software version 4.0. Mol Biol Evol 24:1596-1599 
Tewari S, Ramteke PW, Garg SK (2003) Evaluation of simple microbial tests for detection of fecal coliforms directly at 44.5 degrees C. Environ Monit Assess 85:191-198

Thompson JD, Higgins DG, Gibson TJ (1994) CLUSTAL W: improving the sensitivity of progressive multiple sequence alignment through sequence weighting, position-specific gap penalties and weight matrix choice. Nucleic Acids Res 22:4673-4680

Troy MS, Rose JB, Jenkins TM, Farrah SR, Lukasik J (2002) Microbial source tracking: current methodology and future directions. Appl Environ Microbiol 68:5796-5803

Walsh TR, Weeks J, Livermore DM, Toleman MA (2011) Dissemination of NDM-1 positive bacteria in the New Delhi environment and its implications for human health: an environmental point prevalence study. Lancet Infect Dis 11:355-362

WHO (World Health Organization) (2008) Guidelines for drinkingwater quality, incorporating 1 st and 2nd addenda, vol 1, Recommendations, 3rd edn. WHO, Geneva

Wilson K (1997) Preparation of genomic DNA from bacteria. In: Ausubel FM, Brent R, Kingston RE, Moore DD, Seidham JG, Smith JA, Struhl K (eds) Current protocols in molecular biology. Wiley, New York, pp 2.4.1-2.4.5

Woese CR, Fox GE (1977) Phylogenetic structure of the prokaryotic domain: the primary kingdoms. Proc Natl Acad Sci USA 74:5088-5090 